\title{
THE EMPOWERMENT OF PRODUCTIVE ZAKAT INFLUENCE ON INDEPENDENCE OF THE COMMUNITY
}

(Case Study: Economic Program by Madina Zone of Dompet Dhuafa, Jampang Village, Bogor, West Java Province, Indonesia)

\author{
Hamzah \\ Bogor Agricultural University \\ Email: hamzahipb3@gmail.com \\ Fifi Fata'tiatul Hidayah \\ Bogor Agricultural University \\ Email: fififatatiatul@gmail.com
}

\begin{abstract}
Empowerment through productive zakat is the effort of the Madina Zone of Dompet Dhuafa to create an independent society by developing business that utilize the potential of the community itself. Empowerment programs are needed by the community to be able to overcome economic in a sustainable manner. The majority of Indonesia's population is Muslim, so one of the empowerment programs that is considered relevant is the empowerment through productive zakat as practiced by Madina Zone of Dompet Dhuafa. The empowerment of community is related to self-reliance. Selfreliance can be achieved through empowerment by involving participation from the community. The purpose of this research is to identify the influence of empowerment through a productive zakat carried out by Madina Zone on community self-reliance. The method used in this study is a quantitative approach supported by qualitative data. The location of this study was in the Jampang Village, Kemang District, Bogor Regency. The results of the study showed a significant level of empowerment in participation and a significant level of participation in self-relience.
\end{abstract}

Key words: Self-reliance, participation, empowerment stages and productive zakat

\section{A. INTRODUCTION}

Bogor Regency is the region that has the largest population in West Java Province with $5,715,009$ people (BPS 2018). Based on population projections in 2017, the population of Bogor Regency has grown by 2.28 percent (BPS 2018). Bogor Regency poverty line has increased from 2016, namely 317,430 to 337,550 in 2017 (BPS 2017).

Community in improving its economic situation requires a program that is able to empower it continuously. The government in this case issued a policy to increase development alignments to the interests of the community. According to Law Number 25 of 2000 concerning to the National Development Program (PROPENAS) in 2000-2004 and the Regional Development Program (BAPPEDA), the purpose of community empowerment is to increase community empowerment through strengthening organizations of local community, poverty alleviation and social protection, increasing community self-sufficiency in order to build people to improve economic, social, and political life. 
Non-governmental organizations in Indonesia in this part have also participated in developing empowerment programs. Empowerment has the meaning of how to make people able to build themselves, improve their quality of life independently, and do not depend on other parties (Karsidi 2001). Community empowerment according to Law No. 6 of 2014 is concerning to village. Village is an effort to develop community self-relience and prosperity by increasing knowledge, attitudes, skills, behaviors, abilities, awareness and utilizing resources through the determination of policies, programs, activities, and assistance in accordance with the essence of the problem and priority needs of village communities. The ultimate goal of community empowerment is the formation of independent individuals and communities.

Community empowerment can be done through various efforts; one of them is through zakat management institutions. Zakat is a form of worship for Muslims, socially means helping among humans (Rosmawati 2014). According to Amalia (2012), the potential of zakat that can be developed to alleviate poverty is zakat, which has a productive dispotion. One of the institutions implementing productive zakat utilization is the Madina Zone of Dompet Dhuafa Institute by empowering the community.

There are many zakat management institutions in Indonesia, including the Amil Zakat, Infaq and Shadaqah Board (BAZIS) that is a government amil institution, which actually came before Dompet Dhuafa. However, Dompet Dhuafa is able to compete with BAZIS and has been widely trusted by the public and the government because it has many experiences in managing zakat, infaq and shadaqah, and endowments (Nurdin 2013). Dompet Dhuafa is not only a charity institution but also a socialhumanitarian institution that is closely related to community development. Dompet Dhuafa in carrying out its social-humanitarian mission established a new institution, the Madina Zone. The Madina Zone of Dompet Dhuafa Institute focuses on the implementation of community empowerment programs through the distribution of zakat funds. This is what makes the writer interested in researching the empowerment carried out by the Madina Zone of Dompet Dhuafa.

Self-reliance for the community is important. Someone who is independent no longer depends on others. Self-reliance in the concept of community empowerment is the level of progress that must be achieved, so that the community can build and maintain its survival based on its own strength in a sustainable manner (Noor 2011). Based on the results of previous studies, self-reliance can be achieved through intensive guidance and counseling (Rosmawati 2014). The result of Arif's research (2010) explains that proper zakat management has a significant effect on the economy through effective mechanisms. Similarly, the result of Kholiq's research (2012) states that the utilization of zakat can encourage mustahiq (receiver of zakat) to have an independent business. This success was achieved by carrying out the stages. According to Hamzah and Neneng's (2012) research results also show that self-reliance is significantly related to empowerment, and the empowerment is carried out with appropriate strategies through business development, financial capital, marketing, and so on. Based on some of the studies it can be concluded that self-reliance is important for the community and it can be achieved through empowerment that involves the participation of the community itself. For this reason, this research is considered important to analyze how the effect of empowerment on community self-reliance.

\section{The Purposes of Research}

The purpose of this study is to analyze the effect of empowerment on community self-reliance. The specific objectives are as follows:

1. To analyze economic empowerment carried out by the Madina Zone of Dompet Dhuafa institution.

2. To analyze the effect of empowerment on the participation of beneficiaries (partners) in the economic empowerment program carried out by the Madina Zone of Dompet Dhuafa institution. 
3. To analyze the effect of participation on the self-reliance of the beneficiaries (partners) in the economic empowerment program carried out by the Madina Zone of Dompet Dhuafa institution;

\section{Community Empowerment}

Empowerment is a personal and or social process, as an effort to realize a strengthening of personal abilities, competencies, creativities and freedom of actions (Robinson 1994). Empowerment aims to help clients gain power, strength and ability to make decisions and actions to be taken and related to the client's itself, including reducing personal and social obstacles in taking action (Nasdian 2014).

Community empowerment is the concept of economic development that encapsulates the values of the community to build a new paradigm of develpoment in people-centered, participatory, empowerment and sustainable (Chambers 1995). The concept of development with the community empowerment model does not merely meet the basic needs of the community but rather as an effort to find alternatives to local economic growth.

Empowerment addresses how individuals, groups, or communities try to control their own lives and try to shape the future according to their wishes (Nasdian 2014). This concept is in line with the thoughts of Karsidi (2001) which says that community empowerment is nothing but providing motivation and encouragement to the community. It is to be able to explore their potential and dare to act to improve their quality of life, including through education for their self-awareness and ability.

Empowerment is done so that community is able to participate to achieve self-reliance (Nasdian 2014). Empowerment is an effort to foster participation and self-reliance so that the community at the individual, group, institutional, and community level has a welfare level that is better than before, has access to resources, has critical awareness, and be able to organize and make social control of all development activities carried out in his environment.

Based on the opinions of some figures and explanations above, it can be concluded that community empowerment is a personal and or social process as an effort to provide or transfer some of the power and ability to the community, so that they are able to recognize the potential and utilize that potential to be able to control their own lives and improve their quality of life which can be seen from their selfreliance. The empowerment process is not instant, but requires time and stages of development in accordance with the level of community readiness.

\section{Empowerment Stages}

The empowerment stage is a continuous effort carried out during the empowerment process. The process of community empowerment according to Andriyani et al. (2017) has three stages, including the awareness phase, the capacitance stage and the power supply stage.

1. The first stage is the awareness phase. In this phase is carried out with the community. The socialization process is carried out by village leaders through village meetings by providing understanding to the community.

2. The second stage is the capacitation stage. Government participation in this stage is needed. The government should have more roles in inviting, inspiring, and stimulating the community. One of the tasks is realized in the good cooperation between the government and the community. The role of the government in this case is to improve human resources through guidance, counseling and training to the community.

3. The third stage is the providing power. Community empowerment can be seen from the role of the government in providing assistance in the form of loan funds to community groups that have businesses and physical assistance to improve facilities and infrastructure. 
Community empowerment is essentially to help the community to recognize their potential and to use this potential to control their lives and improve their quality of life. The quality of people's lives can be seen from their independence. Empowerment is done so that community members are able to participate to achieve independence. Nasdian (2014) states that "the empowerment is a road to participation"; it means that empowerment will provide a way for the community to participate in a program.

\section{Participation}

Participation is someone who joins a social group to take part in the activities of their community, outside of work or their own profession (Mardikanto 2010). Nasdian (2014) said that participation is an active process, initiatives are taken by the community members themselves, guided by their own ways of thinking, by using tools and processes (institutions and mechanisms) that they can assert control effectively.

Salam (2010) quoted from Arnstein (1969) suggesting the classification of community participation in planning into eight steps or levels based on the power level granted to the community. Arnstein stated that in planning work organized and funded by the government, basically eight levels could be identified, namely (1) manipulation, (2) therapy, (3) information, (4) consultation, (5) placation, (6) partnership, (7) delegated power, and (8) citizen control.

The lowest clarification (1) and (2) are not participation, but the community is only used as an object of an activity. The next three classifications (3), (4), (5), are the degree of "appreciation" or "tokenism", which is when the public has been invited to talk about their desires and ideas, but the decision taken is in the hands of the government. Classifications (6), (7) and (8) are at the core of Arnstein's ideas about community participation in the degree of power of the community already contains the division of rights, responsibilities, and authority between the community and the government. Furthermore, with the ability of community members to participate, it is hoped that the community can achieve independence, which can be categorized as intellectual independence, material independence, and management independence.

\section{Community Independence}

Independence in the concept of community empowerment is the level of progress that must be achieved so that the community can build and maintain its survival based on its own strength in a sustainable manner (Noor 2011). The main consequences and responsibilities in development programs through the empowerment approach are empowered people. The intended strength can be seen from the physical and material aspects, economic, institutional, cooperation, intellectual strength and joint commitment in applying the principles of empowerment (Sumardjo 1999).

Independence grows because of participation in an empowerment. Nasdian (2014) categorizes independence into three parts, namely:

1. Intellectual independence

Intellectual independence is the basic formation of autonomous knowledge by the community that allows them to cope with finer forms of domination that arise outside the control of that knowledge. The meaning of intellectual independence according to Marliati et al. (2010) is the ability to use land, time, and opportunities to increase productivity and income, the ability to make rational decisions, the ability to solve problems, and others. Anwar (2009) defines intellectual independence as a person's ability to think critically and systematically.

2. Material independence

Material independence is the productive ability to meet basic material needs as well as reserves and mechanisms to be able to survive in times of crisis. Marliati et al. (2010) 
describes material independence as an ability to invest in business development and be able to meet basic needs. In the other side, Anwar (2009) defines material independence as the ability to meet the needs of clothing, food, shelter, and property. Independence according to Anwar (2009) will be achieved with assistance that can help increase income through a community-based micro business and individuals, and supported by the presence of a cooperative.

3. Management independence

Management independence is an autonomous ability to foster self, undergo, and manage collective activities so that there is a change in their life situation. Marliati et al. (2010) defines management independence as the ability to make plans, carry out accroding to plans, evaluate, and apply efficient principles. Anwar (2009) describes management independence from community institutions. Management independence can be achieved through organizing in groups, for example through good financial management, cooperation with partners, clear work systematics. Based on the explanation, it can be concluded that the management independence is the ability to make plans, carry out according to plan, evaluate the business, good financial management, and clear work systematic in running the business.

\section{Productive Zakat}

Zakat is one of the five strategic instrumental values. It is very influential on human and community economic behavior and general economic development (Sartika 2008). Zakat also functions as a source of socio-economic funding for Muslims. Zakat has a strategic role in efforts to reduce poverty or economic development. According to the term of zakat, it means the obligation of a Muslim to issue a net value of wealth that is sufficient for one Nisab, given to mustahiq zakat (receiver of zakat) with some predetermined conditions (Fuadi 2016). One of the verses of the Qur'an that discusses about zakat is in Surat At-Taubah verse 60 whose translation is as follows:

"The alms are only for the poor and the needy, and those who collect them, and those whose hearts are to be reconciled, and to free the captives and the debtors, and for the cause of Allah, and (for) the wayfarer; a duty imposed by Allah. Allah is Knower, Wise."

Based on the socio-economic perspective, Sartika (2008) states that zakat can develop into a social concept, namely the concept of how humans should carry out social life including the economic forms. The term productive zakat is intended so that some zakat funds can be channeled with productive patterns, in addition to be distributed in the form of consumption to eight recipients of zakat (Nurlaila 2013). One of the characteristics of the productive zakat program is the existence of an assistance pattern for the mustahiq (receiver of zakat) (Pratama 2015).

\section{Theoritical Framework}

The empowerment program carried out by Madina Zone. It aims to form an independent community by utilizing the potential of the community itself. This empowerment is done by channeling zakat funds for productive activities or called productive zakat. Through the efforts of assistance, direction and training, it is hoped that the beneficiaries can achieve independence.

Empowerment in the distribution of productive zakat funds can be seen from three parts (Andriyani et al. 2017). The success of an empowerment program can be achieved if there is a participation in each of the empowerment processes. The level of community participation can be seen from the eight levels of empowerment participation (Arnstein 1969). The concept of empowerment is closely related to independence. Independence according to Nasdian (2014) is grouped into intellectual independence, material independence, and management independence. 


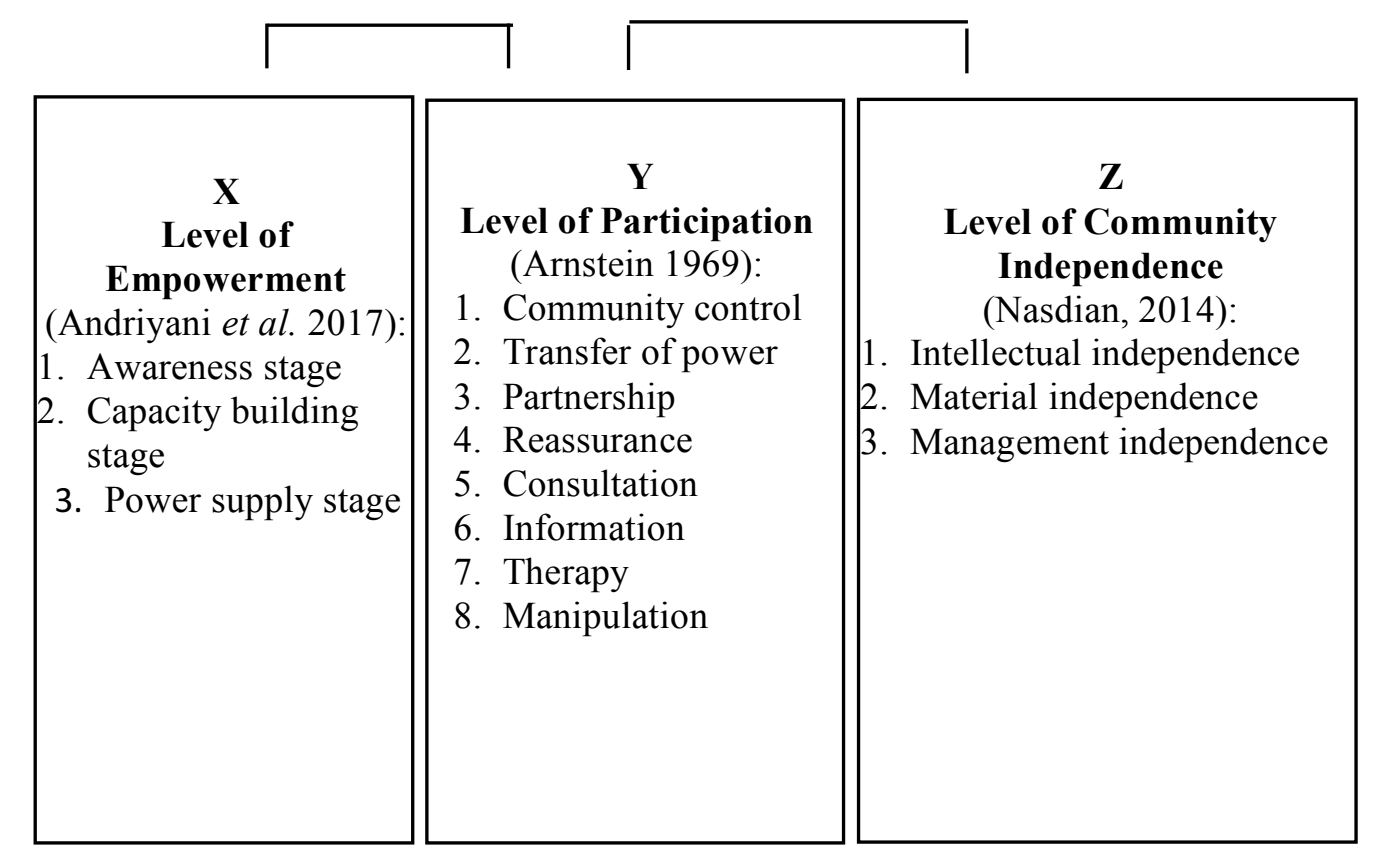

Caption

: Influential

Figure 1: The framework of thinking of the empowerment efefects on community independence.

\section{Hypothesis}

Based on the framework that has been designed, the hypothesis in this study are as follows:

1. It is suspected that there is an influence between the level of empowerment and the level of community participation.

2. It is suspected that there is an influence between the level of community participation and the level of community independence.

\section{B. METHOD}

\section{Research Approach}

This study uses a quantitative approach. Quantitative approach is used to test theoretical or hypothetical hypotheses (Effendi and Tukiran 2014). The quantitative approach in this study was carried out by survey research methods. Before being tested in the field, validity and reliability tests are first performed. Validity and reliability tests were carried out in the same location by taking as many as 10 respondents. This research was also supported by collecting qualitative data through in-depth interviews. The results obtained from in-depth interviews are recorded in the field notes and used to strengthen the deeper answers obtained from the quantitative approach. Quantitative data were obtained using a questionnaire given to respondents; while qualitative data were obtained, using indepth interview questions to informants namely managers, heads of "program divisions", program assistants from the Madina Zone of Dompet Dhuafa, and heads of Jampang Village. 


\section{Research Location and Time}

Research on the effect of empowerment on community independence was carried out in Jampang Village, Kemang District, Bogor Regency, West Java. The selection of research sites was carried out deliberately (purposive) by considering the following matters:

1. Madina Zone of Dompet Dhuafa is one of the institutions implementing the empowerment program in Bogor Regency.

2. Madina Zone was made a pilot institution for empowerment programs.

The implementation of research activities will be carried out within a period of nine months from January 2019 to September 2019. This research includes the preparation of research proposals, colloquium submission of proposals, improvement of research proposals, data collection, processing and analysing data, writing thesis report drafts, pick test, trial thesis, and thesis report improvement.

\section{Data Types and Data Collecting Techniques}

The data needed in this study is primary data and secondary data. Primary data were obtained directly using questionnaires, in-depth interview question guides, and field observations at the study site. The in-depth interview questions guide to selected informants is used to retrieve data that corroborates the data from the questionnaire. Whereas secondary data retrieval is obtained through literature studies from various scientific sources such as scientific journals, articles, theses, dissertations, books, profile of Madina Zone of Dompet Dhuafa, RKAT Madina Zone, and previous studies. Validity and reliability tests will be conducted on ten respondents before the research is carried out. Reliability tests were carried out using the Alpha-Cronbach method. Quantitative data collection is done by using a questionnaire given to respondents, while in-depth interview questions to selected informants.

\section{Determination of Respondent and Informant Techniques}

Subjects taken in this study were respondents and informants. Respondents are to get quantitative data meanwhile informants are used to get qualitative data. The populations in this study are beneficiaries or commonly referred to as partners in the Madina Zone of Dompet Dhuafa economic empowerment program. The sample framework in this study was 40 individuals of beneficiaries from the Madina Zone of Dompet Dhuafa economic empowerment program. The unit of analysis used is individuals. The number of samples taken in this study was 30 respondents. Respondents in this study were determined by the simple random sampling method. In this study, a simple random sampling method was used because there were only forty people in the population, and ten of them were respondents for the validity and reliability tests. Therefore, from that number, thirty members of the population were chosen to be respondents, and the numbers are the minimum amount in a quantitative study that can be processed.

Informants are those who provide true and complete information about this research. The selection of informants in this study was carried out deliberately (purposive) consisting of managers, heads of "program divisions", program assistants from the Madina Zone of Dompet Dhuafa, and heads of Jampang Village.

\section{The Techniques of Processing and Analysing Data}

This study has two types of data that are processed and analyzed, namely quantitative data and qualitative data. Quantitative data obtained through questionnaires that have been filled out by respondents will be entered into Microsoft Excel 2010, and then presented in the form of frequency tables and cross tabulations. Furthermore, to see the effect between variables, a linear regression test was performed using the Statistical Application for Social Science (SPSS) 16.0 for Windows. Qualitative data is used to support quantitative data through three stages of reducting data, making description, 
presenting data, and drawing conclusions to strengthen research results. The first stage is reducting data, which starts with the selection and simplification of data from in-depth interviews, observations, and document studies. The second stage is making description, presenting data by compiling all information and data obtained into a series of words that are easy to read into the report as quotes and narratives. The third stage is verification, which is a conclusion from the results that have been processed at the reduction stage to support quantitative data.

\section{RESULT AND DISCUSSION}

\section{General Overview of Madina Zone of Dompet Dhuafa}

Madina Zone is a part of Dompet Dhuafa under the foundation's management, and acts as a productive waqf manager and technical implementer. Madina Zone of Dompet Dhuafa was built on 3.6 hectares of land in Jampang Village, Kemang District, Bogor Regency. The construction of the Madina Zone began on January 7, 2009. The Madina Zone was established with the concept of a growing and integrated area with a foundation of Islamic values that is rahmatan lil alamin (a mercy to all creation) with the aim of forming the empowered and independent community.

All programs carried out by Madina Zone use zakat funds. They carry out programs in various fields of life consisting of economics, education, health, and culture. The Madina Zone was formed with all the real reasons for the importance of an integrated area that is able to demonstrate work with an integrated awareness that is not only driven by financial capability, but also with a set of planned and measured service work, and has a noble mind.

The vision of Madina Zone of Dompet Dhuafa is the realization of an integrated, empowered and worldwide Madina Zone area through the management of ZISWAF (Zakat, Infaq, Giving Alms, and Endowments) in 2020. The missions of the Madina Zone of Dompet Dhuafa Institution are:

1. Optimizing the role of the Madina Zone as an integrated area coordinator,

2. Creating empowered people through integrated programs,

3. Making model of the international ZISWAF management area,

4. Realizing the worldwide of Jampang silat village.

The purpose of the Madina Zone of Dompet Dhuafa is to glorify and improve the welfare as many people as possible through community empowerment in the Madina Zone empowerment area and to make Madina Zone as the best empowerment model.

\section{Overview of Research Respondents}

The respondents in this study were 30 people who were the beneficiaries (Madina Zone partners). Respondents in this study were spread in four districts namely Kemang District, Parung District, Tajur Halang District, and Ciseeng District. Respondents in the study also have different types of businesses, namely home-based businesses, healthy snack businesses, selling in Madina Zone canteens, mushroom businesses, tofu businesses, and blacksmith businesses.

Based on the total research respondents of 30 people, the majority of respondents were female by 70 percent, and the majority was in the 30-50 years age group, which was 76.7 percent. The respondent's inclination of 36.7 percent had the last level of education namely senior high school, 33.3 percent of elementary school graduates and the rest of them did not attend school and diploma graduates (D3). All respondents in this study were married and 66.7 percent had more than four members in families. The tendency of respondents as much as 66.7 percent had an income of about two to five million and the average business in the food sectors. Most of the models obtained by respondents were once, namely 60 percent, two until three times as much as 36.7 percent, and only one respondent received funding more than three times. The amount of funds received by respondents also various depending on the needs in their businesses. There are 46.7 percent of respondents received funds of one to five 
million. Funds obtained by respondents ranging from $\mathrm{Rp} 200,000$ to $\mathrm{Rp} 60,000,000$ with two different systems, namely grants and loans.

\section{THE ECONOMIC EMPOWERMENT OF MADINA ZONE OF DOMPET DHUAFA}

The economic empowerment carried out by the Madina Zone of Dompet Dhuafa begins with the granting and lending of business funds to partners. Before economic empowerment is carried out, there are several stages undertaken by the Madina Zone, namely:

1. Conduct program planning based on the program planning matrix

2. Program planning per region

3. Socialization to the community

4. Mapped programs and regions will be developed

5. Analysis of potential beneficiaries

6. Formation of groups

7. Routine guidance

The empowerment level undertaken by the Madina Zone of Dompet Dhuafa is relatively high. According to Andriyani, there are three stages carried out, namely the awareness phase, the capacitance stage, and the power supply stage. The empowerment results in the Madina Zone of Dompet Dhuafa economic program indicate that the empowerment undertaken is quite high at 96.7 percent. After the economic empowerment, there are some changes occur in various aspects, including awareness, network, knowledge, income, and management. The measurement results at the awareness stage showed that 96.7 percent were classified as high, it means that the awareness process carried out by Madina Zone was already effective, it gives the high awareness of beneficiaries. Awareness conducted by the Madina Zone of Dompet Dhuafa is through socialization to the potential beneficiaries. The socialization was carried out face-to-face to introduce economic programs, including the systematic implementation of the program, the benefits, and the stages that must be carried out. The capacitance stage also showed a high result of 96.7 percent. Capacity building conducted by Madina Zone is conducting some trainings and activities, and the most important thing is the facilitator who assists each beneficiary in an intense manner. The power supply phase, which included financial assistance, energy, physical facilities and motivation, showed high results at 100 percent. All beneficiaries receive business funds in different amounts per beneficiary. The amount provided by Madina Zone is adjusted to the needs of the beneficiary's business, and is based on decisions between the two parties. The power assistance provided by Madina Zone is in the form of Madina Zone participation in marketing its partner products. There are some physical facilities assistance given, namely, facilitating some equipments that can be borrowed by partners to run their businesses, such as a seasoning mixer, oilfiltering machine, and so on. Madina Zone also always monitors the business run by its partners.

The economic empowerment carried out by the Madina Zone of Dompet Dhuafa provides a change in the economic aspects of the beneficiaries program. Based on the interviews results with informants and respondents in this study, here are some changes that emerged after the existence of the Madina Zone of Dompet Dhuafa economic program:

1. The majority of the community around the Madina Zone only knows the type of work that already exists. Now, people are aware that they have the potential to be developed into a business and can make money. Therefore, people are motivated to have a business without relying on outsiders.

2. The communities between villages are not so connected to each other so that those who have businesses have information coverage and a narrow network. Today, the Madina Zone economic program often brings beneficiaries from different villages, thereby expanding network and information access. 
3. The businesses run by beneficiaries armed only with the knowledge they have. Now, through the training, workshops, exhibitions and activities in economic programs, the beneficiaries have new and broader knowledge both knowledge related to their business and general knowledge.

4. Homemakers who do not have a job or business only depend on the husband's income. Now, homemakers are educated to be able to have a business, so that they can earn income that can help meet their needs.

5. Some respondents previously had a group business, but it was managed with poor management, such as in terms of production, finance, marketing, and so on. Now, beneficiaries who already have a business group, have increased their capacity so that they are able to improve management in running their businesses, such as clear group structures, tasks division, marketing management, financial management, and so on.

\section{PARTICIPATION OF BENEFICIARIES (PARTNERS) IN THE ECONOMIC EMPOWERMENT PROGRAM OF MADINA ZONA OF DHUAFA DOMPET}

Participation in the context of development has the meaning of cooperation between the people and the government in planning, implementing and developing the results (Soetrisno 1995). Implementation of empowerment programs will not be achieved without good participation from the community. Arnstein (1969) classified the levels of participation into eight levels namely manipulation, therapy, informing, consulting, calming, partnership, delegation of power, and community control. The levels are classified again into three, namely the level of manipulation and therapy is the degree of non-participation. The levels of informing, consulting, and calming are degrees of appreciation and levels of partnership, delegation of power, and community control, are degrees of realization of participation. As many as 24 respondents or 80 percent of all respondents indicated the degree of realization of participation, and as many as 20 percent indicated the degree of appreciation or tokenism. There are six respondents who showed a degree of appreciation were partners who rarely and never even participated in training and activities carried out by the Madina Zone of Dompet Dhuafa. They only borrow funds from the Madina Zone without being involved in activities organized by the Madina Zone.

Participation in this study looks at how beneficiaries are involved in economic empowerment programs that consist of involvement in socialization regarding the distribution of funds and about activities during the empowerment program, involvement in program implementation, to involvement in evaluation and monitoring. This refers to the thinking of Cohen and Uphoff (1977) which divides participation into the decision making stage, the implementation stage, the outcome enjoyment stage, and the evaluation stage.

According to Cohen and Uphoff (1977), the decision-making stage was realized by community participation in meetings. Before giving funds, Madina Zone first provides information to potential beneficiaries. This socialization is carried out face-to-face with potential beneficiaries, so that all beneficiaries can get a clear explanation. This socialization discussed many things, it is especially about the amount of funds and potential beneficiaries would run the business planning. The socialization is carried out in large groups, thoset are socialization regarding the systematic disbursement of funds. The next stage after the socialization is the disbursement of loan funds and training.

The training provided by Madina Zone varies according to the needs of partners. Partners who have a healthy hawker business receive training in the form of wares hygiene and financial management. The training on cleanliness of food stalls, food hygiene and financial management was also provided to partners involved in the Madina Zone canteen. They also received training on photography for photos of food products for sale, and English training. Photography training is also given to partners who have 
a home business. The intended home-based business is a partner that produces a product in its own home.

There are various products produced by Madina Zone partners, such as herbs, cassava chips, banana chips, catfish chips, shredded catfish, potato chips, wet cakes, and so on. The partners who produce herbal medicine are given training by going to school in herbal schools for one week where the material providers are those who are experts in the herbal world. Besides herbal school, his product was also tested for two months to improve its quality. The Madina Zone directly controls this. Another homebased business is the production of chips. The types of products to be made by partners are determined solely by the partners concerned, without compulsion from the Madina Zone. Partners who have a chip business receive training in the form of photography, financial management, PIRT permit training, halal permits, packaging training, and marketing. This training was not only carried out in the Madina Zone location, but also through activities with agencies such as the Industry and Trade Office, and the UMKM Office. Zona Madina is also involved in evaluation and monitoring program. Companions from the Madina Zone visit their partners regularly at least once a month. During the visit, the facilitator monitors how the business is being carried out by its partners. The partner also participates in providing information about the condition of its business and provides feedback in the form of providing input and suggestions to the Madina Zone if necessary.

\section{THE EFFECT OF EMPOWERMENT THROUGH PARTICIPATION OF BENEFICIARIES (PARTNERS) OF THE MADINA ZONE OF DOMPET DHUAFA}

Karsidi (2001) says that community empowerment is nothing but giving motivation and encouragement to the community to be able to explore their potential and dare to act to improve their quality of life, among others through education for their self-awareness and ability. Empowerment is done so that community members are able to participate to achieve independence (Nasdian 2014). The results showed that statistically empowerment affected participation significantly. This is due to the statistical tests showing the t value of 4.769 , which indicates higher than $t$ table used in this study, is 2.048. The regression equation for empowerment factors that affect the participation of respondents in the Madina Zone of Dompet Dhuafa economic empowerment program is as follows:

$$
Y=-3,051+2,023 X
$$

Information:

Y: Participation

\section{$\mathrm{X}$ : Empowerment}

$Y$ variable is the dependent variable that is the level of participation. Variable $X$ is empowerment. This regression equation means that participation is influenced by an empowerment rate of 2,023. This means that every $1 \%$ increase in the value of empowerment, the value of participation increases by 2,023 .

Based on the test results, the effect of empowerment with participation shows a significant effect with a sig value smaller than 0.05 that is equal to 0,000 . Empowerment regression coefficient value has a positive value of 2.023; it means that each addition of one percent empowerment value, the value of participation increases by 2.023 .

The Madina Zone of Dompet Dhuafa economic program is carried out with an empowerment model that includes funding, training, coaching, and various activities. Empowerment is carried out with a variety of activities and coaching that makes the community participate in each activities. Nasdian (2014) says that the starting point for participation is to decide, act, and then they reflect the action as a conscious subject. Based on the results of interviews with informants and respondents in this study, the following 
are some changes in partners' participation before and after the Madina Zone of Dompet Dhuafa economic program:

1. The beneficiaries are not familiar with Madina Zone so they are not involved in program planning, especially economic programs. Now, beneficiaries are familiar with Madina Zone and know that there are economic programs that can help them, so they are directly involved in the planning process.

2. The beneficiaries are struggling with the group, so they only contribute their thoughts to the group. Now, beneficiaries are not only contributing ideas and being involved in their groups, but they are already involved in the Madina Zone economic program, which is also wider because they have relationships with other partners.

3. The benefits can only be felt by members of the group. Now, the benefits of the program are felt not only by group members, but also by Madina Zone.

4. The implementation of the evaluation is limited to its internal capabilities. Now, the evaluation for the business has involved to the Madina Zone, it means the feedback process is better and if there are problems in the business, it can be solved more effectively.

\section{THE INDEPENDENCE OF BENEFICIARIES (PARTNERS) OF THE MADINA ZONE OF DOMPET DHUAFA IN THE ECONOMIC EMPOWERMENT PROGRAM}

Independence in the concept of community empowerment is the progress level that must be achieved so that the community can build and maintain its survival based on its own strength in a sustainable manner (Noor 2011). The group independence can be seen from various aspects, one of them is the higher income and social capabilities. An independent person or group is no longer dependent on other parties out of the internal (Dwirayani 2015).

The results showed that all respondents in this study had a high level of independence. According to Nasdian's opinion (2014), that independence is categorized into three parts, namely intellectual independence, material independence, and management independence. The meaning of intellectual independence according to Marliati et al. (2010) is the ability to use land, time, and opportunities to increase productivity and income, the ability to make rational decisions, the ability to solve problems, and others. In this study, it is analyzed how the beneficiaries run their businesses related to the use of time and funds; manage needs, opportunities, and how to solve problems. The results showed that the intellectual independence of the beneficiaries was classified in the high category. The business carried out by the beneficiaries is run entirely by them, and external parties such as the Madina Zone are only helping them. The beneficiaries of productive zakat have different businesses. Each has their own time and knowledge in starting their businesses.

The utilization of funds by partners is determined based on the needs in running their business. Mushroom and tofu businesses use Madina Zone funds for asset procurement. Whereas healthy snacks and home-based businesses allocate funds for the procurement of tools and materials. The results also showed that the material independence of productive beneficiaries was relatively high. The results showed that as much as 90 percent of respondents were classified as having high material independence, and 10 percent were classified as moderate. Respondents whose material independence is moderate, they stated that the income earned could not cover the family's living needs. This is because the results of their effort are not too high, in their family, there are children who are still in school so that their income is allocated for education funds, and this is quite burdensome. Respondents whose material independence is high are beneficiaries whose economic condition has improved since they owned a business. Based on the study results, respondents acknowledged that the existence of productive zakat from the Madina Zone was very beneficial for them. There are some respondents who initially did not have any business, but after there was a productive zakat program, 
they followed the program and training until now, they are able to have their own businesses. There are also those who initially joined in a business group, but the management is not good so the results are not optimal. After there was an economic empowerment program from the Madina Zone, they admitted that it was very helpful and could improve the previous conditions.

The results of this study also indicate that the independence of the respondents' management is relatively high. Marliati et al. (2010) defines management independence as the ability to make plans, carry out based on plans, evaluate, and apply efficient principles. In this study, the independence of respondent management is seen from how respondents plan and carry out their business activities, how financial management, how to evaluate, and coordination in their business activities. Some beneficiaries say that the management of their businesses has not changed a lot from the past until now. These respondents said that the success and failure of the business they run depends on themselves.

\section{THE EFFECT OF PARTICIPATION ON INDEPENDENCE OF BENEFICIARIES (PARTNERS) OF THE MADINA ZONE OF DOMPET DHUAFA}

Nasdian (2014) says that empowerment is done so that community members are able to participate to achieve independence. The results showed that statistically empowerment affected participation significantly. This is due to the statistical tests showing the value of $t$ arithmetic of 3.571 that indicates higher than $t$ table used in this study is 2.048 . The regression equation for participation factors that influence the independence of respondents in the Madina Zone of Dompet Dhuafa economic empowerment program is as follows:

$$
Y=22,134+0,125 X
$$

Information:

Y: Independence

$\mathrm{X}$ : Participation

The $Y$ variable is the dependent variable, which is the independence level. The variable $X$ is participation. This regression equation means that independence is influenced by the participation level of 0.125 . This means that every $1 \%$ increase in the value of participation, the value of independence increases by 0.125 .

Based on the test results, the effect of participation with independence in appendix 3 can be seen that the effect of participation on independence in this research is significant because it has a sig value less than 0.05 that is equal to 0.001 . The value of the participation regression coefficient has a positive value of 0.125 , which means that for each addition of one percent of the participation value, the independence value increases by 2,023 .

Based on the information from respondents and informants in the study, the following concludes some changes in the independence of beneficiaries before and after receiving an economic empowerment program:

1. Some effort that were run before participating in the Madina Zone economic program, it is only equipped by their own knowledge, while nowadays the beneficiaries get knowledge that was not previously known so as to increase their creativity.

2. Some partners are initially only homemakers who have no income. Nowadays, they have their own income and do not depend on the husband's income. 
3. Initially, business partners in the form of groups do not have good management skills. Nowadays they are able to manage businesses and groups better, for example management in the types of products to be produced, marketing targets, financial management, and so on.

\section{CONCLUSIONS}

Based on the research results, the following conclusions are obtained:

1. Economic empowerment carried out by the Madina Zone of Dompet Dhuafa consists of three stages, namely the awareness stage, the capacity building stage, and the power supply stage. The field study results stated that the stages of empowerment were in the high category. This program is carried out by providing good training and assistance to achieve high partner capacity, as well as facilitated funds, energy assistance, physical facilities, and motivation so that partners are able to empower their own potential through economic ventures.

2. Empowerment carried out by Madina Zone of Dompet Dhuafa has a significant influence on the participation of beneficiaries. This shows that empowerment is considered important for beneficiaries. Therefore, the beneficiaries actively participate in activities in economic empowerment in the Madina Zone of Dompet Dhuafa.

3. The participation level of productive zakat beneficiaries in the Madina Zone of Dompet Dhuafa has a significant influence on the level of independence. Beneficiary participation starts from socialization, implementation, until evaluation influences through knowledge, income, network, and so on.

\section{Suggestions}

Based on the research results, there are a number of suggestions that can be used as input for consideration:

1. There is a need for more creative capacitance that is able to involve all partners without being constrained by subjective reasons.

2. Based on the results of this study, it appears that some partners do not really need financial assistance from the Madina Zone. For this reason, in the future Madina Zone needs to improve planning more effectively so that the empowerment program undertaken is not misplaced.

3. The increasing creativity of the community should be able to compete in the global area. For this reason, training provided by Madina Zone of Dompet Dhuafa should be able to create partners who are able to develop, not only in the local area but also in the national level by cooperating various stakeholders who are sustainable with the target of empowerment program achievements in the economic field.

\section{REFERENCES}

Amalia, Mahalli K. 2012. Potensi dan peranan zakat dalam mengentaskan kemiskinan di Kota Medan. Jurnal Ekonomi dan Keuangan. 1 (1): 70-87. [diunduh 25 Februari 2019]. Tersedia pada: 
https://222.neliti.com/publications/14869/potensi-dan-peranan-zakat-dalam-mengentaskankemiskinan-di-kota-medan.

Andriyani AAI, Martono E, Muhammad. 2017. Pemberdayaan masyarakat melalui pengembangan desa wisata dan implikasinya terhadap ketahanan sosial budaya wilayah (Studi di Desa Wisata Penglipuran Bali). Jurnal Ketahanan Nasional. 9(1); 71-79. [diunduh 8 Januari 2019]. Tersedia pada: https://doi.org/10.22146/jkn.18006.

Anwar MS. 2009. Arti kemandirian untuk sebuah perubahan. [Internet]. [diunduh 25 Februari 2019]. Tersedia pada: https://ddsumsel.org/arti -kemandirian-untuk-sebuah-perubahan/.

[BPS] Badan Pusat Statistik. 2018. Jumlah Penduduk dan Laju Pertumbuhan Penduduk menurut Kabupaten/Kota di Porvinsi Jawa Barat, 2010, 2016, dan 2017. [Internet]. [diunduh 29 September 2018]. Tersedia pada:

https://jabar.bps.go.id/publication/2018/08/16/d8b96de222796402938666e4/provinsi-jawabarat-dalam-angka-2018.html.

[BPS] Badan Pusat Statistik. 2018. Garis Kemiskinan dan Jumlah Penduduk Miskin di Kabupaten Bogor, 2010-2017. [Internet]. [diunduh 29 September 2018]. Tersedia pada:

https://bogorkab.bps.go.id/publication/2018/08/16/bdef1d026493e5275090e32f/kabupatenbogor-dalam-angka-2018.html.

Dwirayani D, Hapsari H, Sendjaja TP. 2015. Analisis faktor-faktor yang berpengaruh terhadap tingkat kemandirian petani mangga gedong gincu. Jurnal IImu Pertanian dan Peternakan. 3 (1): 2332. [diunduh 26 September 2018]. Tersedia pada:

http://www.unma.ac.id/jurnal/index.php/AG/article/viewFile/387/366.

Fuadi. 2016. Model dan peranan lembaga zakat. Jurnal Akad. 1 (1): 104-119. [diunduh 10 Desember 2018]. Tersedia pada: http://ojs.serambimekkah.ac.id/index.php/akad/article/view/22.

Girsang LJ. 2011. Faktor yang Mempengaruhi Partisipasi Masyarakat dalam Kegiatan Perbaikan Jalan (Kasus: Program Nasional Pemberdayaan Masyarakat (PNPM) Mandiri Perdesaan di Desa Megamendung, Bogor) [Skripsi]. [diunduh 30 Februari 2019]. Tersedia pada: https://fdokumen.com/document/faktor-yang-memengaruhi-partisipasi-masyarakat-dalamkegiatan-2015-09-03.html.

Hamzah, Hasanah N. 2012. Faktor-faktor yang mempengaruhi kemandirian anggota kelompok (mustahiq zakat) pada program pemberdayaan masyarakat di Desa Sukadamai Komplek Budi Agung Tanah Sereal Bogor. Jurnal Kajian Pendidikan Umum. 10(1): 40-58. [diunduh 26 September 2018]. Tersedia pada: http://repository.ipb.ac.id/handle/123456789/74524.

Karsidi R. 2001. Paradigma Baru Penyuluhan Pembangunan dalam Pemberdayaan Masyarakat. Bogor (ID): Penerbit Pustaka Wirausaha Muda.

Kholiq A. 2012. Pendayagunaan zakat, infak dan sedekah untuk pemberdayaan ekonomi masyarakat miskin di Kota Semarang. Jurnal Riptek. 6(1): 1-7. [diunduh 26 September 2018]. Tersedia pada: http://bappeda.semarangkota.go.id/v2/wpcontent/uploads/2013/12/4.Exsecutive_Summary_final_zakat-Repaired.pdf.

Mardikanto T. 2010. Konsep-Konsep Pemberdayaan Masyarakat. Surakarta [ID]: UNS Press.

Marliati, Sumardjo, Pang SA, Tjitropranoto P, Saefuddin A. 2010. Faktor-faktor yang berpengaruh terhadap kemandirian petani tanaman pangan beragribisnis di Kabupaten Kampar, Proinsi Riau. Jurnal Forum Pasca Sarjana. 33 (3): 221-228. [diunduh 27 Februari 2019]. Tersedia pada: http://jurnal.ipb.ac.id/index.php/forumpasca/article/view/4984.

Nasdian FT. 2014. Pengembangan Masyarakat. Jakarta (ID): Yayasan Pustaka Obor Indonesia.

Noor M. 2011. Pemberdayaan masyarakat. Jurnal IImiah CIVIS. 1 (2): 87-99. [diunduh 2018 Desember 19]. Tersedia pada: http://journal.upgris.ac.id/index.php/civis/article/view/591.

Nurlaila, Hasnita N. 2013. Tingkat keberhasilan program pendayagunaan zakat produktif pada Baitul Mal Provinsi Aceh. Jurnal SHARE. 2 (2): 170-187. [diunduh 3 November 2018]. Tersedia pada: https://www.google.co.id/url?sa=t\&source=web\&rct=j\&url=http://jurnal.ar.raniry.ac.id/index.php/ 
Share/article/download/1497/1095\%ved=2ahUKEwjMg9f0kaffAhWLql8KHbZsAPMQFjAAegQI BBAB\&usg=AOvVaw3TfbJmgNOwj8Z05HjYdWuq.

Nurdin A. 2013. Transformasi Dompet Dhuafa dari Lembaga Amil Zakat menjadi Lembaga Sosial Kemanusiaan. Jurnal Buletin Al-Turas. 19(2): 345-368. [diunduh 19 Maret 2019]. Tersedia pada:http://journal.uinjkt.ac.id/index.php/al-turats/article/view/3725.

Rosmawati R. 2014. Pengembangan potensi dana zakat produktif melalui Lembaga Amil Zakat (LAZ) untuk meningkatkan kesejahteraan masyarakat. Jurnal Padjajaran, Jurnal Ilmu Hukum. 1(1): 175-191. [diunduh 5 Oktober 2018]. Tersedia pada: http://jurnal.unpad.ac.id/pjih/article/view/7063.

Salam MR. 2010. Partisipasi Masyarakat dalam Peningkatan Kualitas Pemukiman Di Kawasan Pusat Kota Palu. [internet]. Jurnal Ruang. Volume 2(2): Hal 8-23. [diunduh 1 Mei 2019]. Tersedia pada: http://jurnal.untad.ac.id/jurnal/index.php/RUANG/article/view/726.

Sartika M. 2008. Pengaruh pendayagunaan zakat produktif terhadap pemberdayaan mustahiq pada LAZ Yayasan Solo Peduli Surakarta. Jurnal La-Riba, Jurnal Ekonomi Islam. 2(1): 75-89. [diunduh 26 September 2018]. Tersedia pada:

http://ejournal.unri.ac.id/index.php/IJAE/article/view/3803. 